\title{
Adrenocortical Dysplasia Protein Homolog
}

National Cancer Institute

\section{Source}

National Cancer Institute. Adrenocortical Dysplasia Protein Homolog. NCI Thesaurus. Code C119709.

Adrenocortical dysplasia protein homolog (544 aa, $\sim 58 \mathrm{kDa}$ ) is encoded by the human ACD gene. This protein plays a role in both the elongation and maintenance of telomeres. 